\title{
What rhyme tells us about the status of homogeneous diphthongs in spanish
}

\author{
Juan Carlos Castillo - University of Northern Iowa \\ juan.castillo@uni.edu
}

Rebut / Received: 10-7-15

Acceptat / Accepted: 29-11-16

Resum. El que ens diu la rima sobre l'estatus dels diftongs homogenis en espanyol. Aquest article estudia l'estatus dels diftongs homogenis en espanyol (és a dir, aquells formats per dos vocals altes, normalment $i$ o $u i)$ per intentar determinar quin dels dos elements vocàlics actua com a nucli de la síl.laba i quin com a semivocal/semiconsonant. La majoria dels autors assumeixen que l'ordre és semiconsonant-vocal (com en un diftong creixent) però sense oferir gran evidència a favor d'això. Un estudi d'exemples de rima de diferents èpoques de poesia i teatre en vers en espanyol confirma la forta tendència d'aquests diftongs a funcionar com a ascendents.

Paraules clau: fonologia, diftongs, diftongs homogenis, rima, espanyol.

Abstract. What rhyme tells us about the status of homogeneous diphthongs in spanish. This article addresses the status of homogeneous diphthongs in Spanish (those formed of two high vocoids, usually spelled $i u$ or $u i$ ) to try to determine which vocoid acts as the syllable nucleus and which is the glide. It has generally been assumed that the order is glide-vowel (rising-like diphthong) but with little factual substantiation. A study of examples of rhyme from different ages in Spanish poetry and theatre in verse confirms the strong tendency for these diphthongs to act as rising-like.

Keywords: phonology, diphthongs, homogeneous diphthongs, rhyme, Spanish. 


\section{Introduction}

The main objective of this article is to shed light on an issue that puzzles anyone who approaches the teaching of diphthongs in Spanish. This is the topic of homogeneous diphthongs, that is, diphthongs that are formed of two high (or closed, or weak) vowels, written in the form $i u$ or $u i$ and their orthographic variants. The issue with these diphthongs is determining which one of the two vocoids is the vowel, and thus the nucleus of the syllable, and which one is the glide, or semiconsonant, or semivowel, and thus whether we are faced with a rising or falling diphthong.

In heterogeneous diphthongs, which are formed by a high, closed or weak vowel ( $i$ or $u$ ) and a non-high, open or strong vowel $(a, e$, or $o$ ), the answer is immediately obvious. The glide is the high vocoid, whose position determines if the diphthong is rising (when the glide precedes the vowel, as in the Spanish diphthongs ia, io, ie, ua, uo, or ue) or falling (when the glide follows the vowel, as in $a i, o i, e i, a u, e u$, or the virtually nonexistent in Spanish ou). This is due to the fact that the high vowel has a more phonetically consonant-like quality, with the tongue placed in a position closer to producing an obstruction like the one seen in consonants. This has led to the proposition that the glide be called a semiconsonant in rising diphthongs or semivowel in falling diphthongs.

With a homogeneous diphthong, in principle, two options arise. Since both vocoids are able to become glides, the diphthong could show the order glide-vowel ([ju] or [wi]), or vowel-glide ([iw] or [uj]). Given that there is no clear distinction in the height of the vowel between these two vocoids, it does not seem appropriate to classify these diphthongs as either rising or falling. Instead, I will describe the variants of these diphthongs as rising-like if the glide precedes the vowel, and falling-like, when the vowel precedes the glide.

While this article will not attempt to find a final answer to the question at hand or an explanation of the facts, its purpose is to contribute evidence towards determining into which category these diphthongs fall. In order to do it, I will perform a survey of linguistic literature to summarize what most scholars of phonetics and phonology have proposed for these diphthongs. Once that is done, this article will study the rhyming patterns in different works in Spanish verse, to try to determine how the rhyme classifies these diphthongs, as rising-like or falling-like.

\section{Descriptions of homogeneous diphthongs}

A review of the literature in phonetics and phonology reveals a clear preference in Spanish to pronounce homogeneous diphthongs as rising-like, with a sequence glide-

\footnotetext{
1. In fact, the Real Academia Española (1973, p. 55), considers it "impossible to determine them as rising or falling", also citing phonetic reasons.
} 
vowel rather than the opposite. Most authors agree that most examples in Spanish take on this form. However, discussions range from stating a categorical choice for the risinglike option to allowing free variation between the two choices. The confusion around these diphthongs is further underlined by the fact that some authors actually contradict themselves, claiming for instance, the availability of both options, only to later list just the rising one in their examples of words or in their lists of possible diphthongs.

Some authors simply state that all homogeneous diphthongs are always risinglike. Navarro Tomás (1957) was the first one to point out the marked preference in standard Castilian towards the rising-like form of the diphthong, although allowing in a footnote some dialectal variations in Northern Spanish dialects, which at the time may have been influenced by language contact. In the same vein, Gili Gaya (1966), Harris (1969), Núñez Cedeño and Morales-Front (1999), Gómez Torrego (2002), Iribarren (2005), Hualde (2005) and Hualde, Olarrea, Escobar and Travis (2010) also describe all homogeneous diphthongs as rising-like without exception or qualification. Some of these authors allow the variation between diphthong and hiatus in some of the cases, be it lexically determined or decided by the level of formality. The only hard evidence is provided by Manrique (1979), whose spectrographic analysis shows that homogeneous diphthongs tend to follow the patterns of rising diphthongs, with the second vocoid having a longer duration than the first one.

Other authors do not say explicitly that the rising-like diphthong is the only option, but the idea emerges from their discussion. Quilis (1988) in principle allows both options, but then only lists examples of rising-like diphthongs. Also, neither Cloutier (2007) nor Cortez de Andersen (2010) nor Morgan (2010) mention homogeneous diphthongs in their discussions, but always list all their examples as rising-like. It is unclear whether these are intended omissions, casual oversights or the simple assumption that this option is the only one.

Other authors allow for variation in the use of these diphthongs as rising-like or falling-like, tying the alleged variation to different factors. For Bello (1884) and Harris (1983), the variation depends on the specific word, although they disagree on which words fall into which category: Bello (1884, pp. 78-79) emphasizes the falling-like examples, perhaps highlighting their rarity; he finds muy 'very' and buitre 'vulture' and provides some examples of rhymes that show cuida '(she) cares', descuido 'carelessness', and viuda 'widow' clearly behave like falling-like diphthongs. Curiously, for Harris, two of these words (cuida and viuda) would be lexically specified as having a rising-like diphthong; other words would be lexically determined as having a falling-like diphthong (muy, ciudad 'city'); Azevedo (2009) and Hualde et al. (2010) agree with Bello and Harris in listing muy with a falling-like diphthong. Little or no evidence is provided for these claims. Hualde et al. (2010, p. 91) argue that emphatic uses of the word muy lengthen the $[\mathrm{u}]$ rather than the $[\mathrm{j}]$ segment, but most of these claims seem to be based on authors' (or their informants') intuitions without any other empirical support, with the exception of Bello's rhyming examples. The Real Academia Española (1973) also 
agrees that the rising-like diphthong is the most frequent, but allows some uneducated uses of the falling-like version, using etymological criteria to distinguish the diphthongs; the nucleus of the syllable corresponds to the vocoid that carried the stress in the original word; this may result in falling-like pronunciations such as [uj] in muy from Latin múltu or cuita from vulgar Latin cógita, and [iw] in viuda from Latin vídua. A final factor included in the RAE discussion is the origin of borrowed words, which also may affect the character of the diphthong and result in the falling-like versions.

For other authors, the variation depends on the specific dialect. Navarro Tomás (1957), as mentioned above, finds the falling-like version, only for the [uj] diphthong, in the Asturian dialect of Spanish; Navarro Tomás does not mention whether this could be influence from the Asturian language spoken in the area at the time. Navarro Tomás also quotes Bello's (1884) mention of the same falling-like diphthong in Chile. D'Introno, Del Teso and Weston (1995) and Azevedo (2009) seem to follow Navarro Tomás in their discussions, not contributing any further evidence or specifics. Regarding the falling-like [iw] diphthong, Navarro Tomás (1957, p. 169) describes it as "archaic and rare", citing a couple of examples from medieval and Golden Age verses.

Finally, other authors leave the variation up to the speaker and possibly to a matter of registers. Alarcos (1964) mentions the difficulty in finding the difference between falling-like and rising-like diphthongs in unstressed syllables (as in ciudad 'city', or cuidado 'care'), but admits the alternation when stressed, switching from idiolectal to register variation. Quilis \& Fernández (1979) also allow idiolectal variation, although they list all examples as rising-like. Harris (1983, p. 139) considers the two options "freely interchangeable" and similarly Eguren and Fernández Soriano (2006) simply allow each vocoid to receive the higher intensity of pronunciation, and do not mention any possible factors that may affect this choice.

Quilis (2003) leaves the question totally open, allowing both options in all cases, and admitting all kinds of variation: idiolectal, dialectal or determined by formality. However, at the same time, all the solutions to the exercises in his book choose the rising-like option for these diphthongs.

As can be seen from the review of the literature, the issue has not been settled. Most authors' claims lack factual evidence or support, and seem based on other authors' ideas or on the authors' own intuitions.

A few authors mention the use of rhyme, but lack any kind of survey, with the exception of Navarro Tomás (1957), who offers a brief set of examples in favor of the different options. In what follows, a more rigorous survey of rhymes in Spanish will be carried out in order to try to find a quantitative answer to the question: are homogeneous diphthongs in Spanish mostly rising-like or do they show variation between rising-like and falling-like? 


\section{Method of study}

The object of study is the cases in which these diphthongs appear in rhyming positions, be it in full or vowel rhyme. In a full rhyme, all sounds rhyme, counting from the last stressed vowel in the verse (to the end); in vowel rhyme, on the other hand, only the vowels participate in the rhyme, beginning again with the last stressed vowel of the verse. Given that homogeneous diphthongs are highly unlikely to appear in post-stress final syllables, almost all the examples in which these diphthongs appear in rhyming areas will serve to discern which of the two vocoids plays a part in the rhyming pattern. There will thus be no need to separate the study of the two kinds of rhyme.

The two diphthongs can appear in different spelling forms. The much less common $i u$ diphthong could in principle appear in stress-marked spellings such as $i u$ or $i \dot{u}$; with a dieresis, as in $\ddot{\imath} u$ or $i \ddot{u}$ (often used in poetry to mark a diversion from normal pronunciation); and, in very few cases, with an interspersed $h$ : $i h u$. It must be said that in practice not all the options may be available, since some of the spellings may not be represented in any actual words in Spanish. ${ }^{2}$

The more common $u i$ diphthong will appear in the equivalent mirror-image spellings, although we also find the spelling $u y$ in the word muy. In addition, Spanish orthography makes use of the dieresis after the letter $g$ to distinguish the cases in which the $u$ is pronounced (agüita 'little water') from those in which the $u$ is not pronounced (guisa 'manner'). As any person versed in Spanish spelling would be able to predict, the many instances of the orthographic sequence $u i$ in which the letter $u$ is not pronounced (following the aforementioned letter $g$, or the letter $q$, as in aqui 'here') will be ignored, as they are not instances of a diphthong.

In addition to these nuances, the search is further complicated by the issue of hiatuses. As mentioned above, in some words, such as the verbs huir 'to escape' and construir 'to build' and their derivatives, the presence of a hiatus in a $u i$ or $i u$ sequence will be lexically determined, and often may vary from one speaker to another. In such cases, there usually is no explicit marking of the hiatus. Furthermore, in other instances, even when the word is normally pronounced with a diphthong, the author may choose to break up a diphthong for reasons of meter or rhyme. In these instances, the author may use dieresis to signal the break up of a diphthong. Therefore, when studying the examples, it will be important to take into account the number of syllables in each verse in its metric context, in order to determine whether the author is using a diphthong or a hiatus.

2. One reviewer points out that orthography in old texts may not represent pronunciation accurately. Obviously, this is an issue of concern for any study of the sound system using old texts. This is also the reason why different alternative spellings have been brought into consideration. The fact that all the examples studied here rhyme with words that include other combinations of sounds (not including the diphthongs under study) should serve as an additional filter to ascertain the assumed pronunciation. 
Occasionally, some examples had to be eliminated because of the impossibility of determining which of the two vocoids are used in the rhyme. Here is an example:

(1) De tan superior talento, ¡cómo podrás, sin perjuicio, hablar en aqueste intento cuando a ti te falta el juicio y a él le sobra entendimiento? 'Of such superior talent, how could you, without harm, speak in this attempt when you lack the judgment and he has understanding to spare?' (Álvarez Amo, 2014, p. 86)

In example (1) we can see how perjuicio 'harm' and juicio 'judgment' only rhyme with each other and with no other word; therefore, it is impossible to discern whether the rhyme is determined by the $[\mathrm{u}]$ or the [i] vocoid of the diphthong in question. Examples such as (1) (not very common, in any instance) have been ignored in this study.

I have studied a series of works in verse in Spanish from different ages. The study covers four different kinds of works found in searchable formats in different online databases: medieval epic poetry (International Online Archive of the Pan-Hispanic Balled), Golden Age theatre in verse (Digital Play Texts and Artelope), the complete works of $18^{\text {th }}$ century poet Eugenio Gerardo Lobo (Álvarez Amo, 2014) and a compilation of sonnets from all the ages (García González, 2007).

I have selected these texts for their availability in a digitized format, which facilitates the search for examples. I believe that this is a representative sample for an initial study such as this one. On the one hand, it is true that not all eras are represented in the sample, but, on the other hand, the production of rhymed texts has decreased over the centuries, with the progressive expansion of theatre in prose, and free verse poetry. It is therefore natural that a majority of the examples come from the Spanish Golden Age $\left(16^{\text {th }}\right.$ and $17^{\text {th }}$ centuries), with their monumental production of rhymed poetry and theatre in verse.

Not all the works in each database have been studied here. Where the available digitized texts were too numerous, as in the case of Golden Age theatre plays, I have made a random but, I believe, representative selection. The method chosen has been to pick the first play or set of rhymed works listed under each letter of the alphabet represented in the database. The resulting sample includes around 850 romances (popular ballads), 100 theatre plays, over 18,000 verses of lyrical poetry and over 5,000 sonnets. This provides a large enough sample to be a reliable representation of the uses studied here. 


\section{Results}

The results of the study show two very clear and overwhelming tendencies. First, there is a tendency to divide the vowel sequences $i u$ and $u i$ into a hiatus. The number and proportion of hiatuses in the data is very large, and in some cases seems to show the authors' lexical choices, varying sometimes from author to author. In other instances, authors may choose the hiatus as a poetic license, consciously marking with a dieresis the apparent rule violation to help the reader complete the verse with the intended meter. Where the author did not explicitly mark the hiatus, it is the meter that allows us to hypothesize the presence of a hiatus. An example of this is found in (2).

(2) Las mudas soledades,

de los pastores nido,

imitan en ruido

'The silent loneliness,

nest for shepherds,

imitates the sound'

(Artelope: Adonis y Venus, verses 775-777)

In (2), the metric environment requires a seven-syllable verse, which can only be achieved if the word ruido 'noise' is pronounced with a hiatus, rather than a diphthong.

As a result of these choices, we find almost as many examples of hiatuses as we do of diphthongs. For the far less common iu combination, in the sample studied, we found 15 examples of hiatus and 32 examples of diphthongs. On the other hand, for the much more common $u i$ combination, we found 365 diphthongs and 366 hiatuses. For the purpose of this study, the hiatuses will be ignored, since they do not shed light on the structure of the diphthong.

The second tendency is that, in the cases in which a diphthong is used, the rising-like option is the overwhelming choice. The results for the iu diphthong are summarized in Table 1.

TABle I: RhyME DATA FOR $I U$ COMBINATIONS

\begin{tabular}{|l|c|c|c|}
\hline & Rising-like & Falling-like & Hiatus \\
\hline Romances & 0 & 1 & 0 \\
\hline Lope de Vega & 2 & 0 & 5 \\
\hline Ruiz Alarcón & 0 & 0 & 0 \\
\hline Calderón de la Barca & 8 & 0 & 0 \\
\hline
\end{tabular}




\begin{tabular}{|l|c|c|c|}
\hline Cervantes Saavedra & 0 & 0 & 1 \\
\hline Mira Amescua & 5 & 0 & 1 \\
\hline Tirso de Molina & 8 & 0 & 1 \\
\hline Other Golden Age comedies & 0 & 0 & 0 \\
\hline E G Lobo & 4 & 0 & 2 \\
\hline Sonetos & 4 & 0 & 5 \\
\hline Total & 31 & 1 & 15 \\
\hline Percentage among diphthongs & 96.875 & 3.125 & \\
\hline
\end{tabular}

In the examples studied for the $i u$ combination, we found 31 examples of rising-like diphthongs $(96.87 \%)$, whereas we only found 1 example of a falling-like diphthong $(3.12 \%)$. The lone dissenting example is shown in (3):

(3) Allí hablara Granada, al buen rey le respondía:

Casada so, el rey don Juan, casada soy, que no viuda;

el moro que a mí me tiene bien defenderme querría.

'Granada spoke there, answered to the good king:

I am married, king Juan, I am married, not a widow;

the moor who owns me would want to defend me.'

(International Online Archive of the Pan-Hispanic Balled, Romance 0051:1 Abenámar, verses 13-15)

As we see in (3), an example of vowel rhyme with an [i] - [a] pattern, the word viuda 'widow' is rhymed with the words respondia 'answered' and querria 'would want', thus picking the first vocoid in the diphthong as the nucleus and the second as the glide, resulting in a falling-like option. It may also be pointed out that the lone falling-like case is found in a medieval text (epic verse). It may also be considered at this point that the percentage of falling-like diphthongs may have been exaggerated by the small sample in the study. A larger number of cases may provide different results.

All the other examples of the $i u$ combination follow the rising-like pattern, as we see in the examples in (4)-(6).

(4) ¡Suerte injusta! ¡Dura estrella!

Señora, no tiene duda

de que mirándote viuda,

tan moza, bizarra y bella,

'Unjust luck! Tough fortune! 
Lady, there is no doubt

that finding you a widow,

so young, brave and beautiful,'

(Digital Play Texts, Calderón de la Barca: La dama

duende, verses 401-404)

(5) vuelva el siglo de Saturno,

pues el gran monarca diurno

'let Saturn's century come back

since the great king of the day'

(Álvarez Amo, 2014, p. 381)

(6) Este mal se me va cuando lo sufro.

Parece que se asusta con mi triunfo

'This illness goes away when I suffer from it.

It seems that my triumph frightens it.'

(García González, 2007: Autores Letra H, p. 21)

In (4), we see the word viuda 'widow' (found above in the lone falling-like example) rhyming with duda 'doubt' in full rhyme. In (5), again in full rhyme, we see diurno 'of the day' paired with Saturno 'Saturn'. Finally, in (6), an example of vowel rhyme, the word triunfo 'triumph' rhymes with sufro '(I) suffer'. In all cases, it is clear that it is the second vocoid in the diphthong that participates in the rhyme, thus confirming the rising-like nature of the diphthong. In these examples, the possibility of a hiatus is discarded since only the diphthong will give us the proper meter (8-syllable in (4) and (5), and 11-syllable in (6)).

The results for the ui combinations are summarized in Table 2.

TABLE 2: RHYME DATA FOR UI COMBINATIONS

\begin{tabular}{|l|c|c|c|}
\hline & Rising-like & Falling-like & Hiatus \\
\hline Romances & 16 & 0 & 24 \\
\hline Lope de Vega & 41 & 0 & 34 \\
\hline Ruiz Alarcón & 24 & 0 & 48 \\
\hline Calderón de la Barca & 44 & 0 & 26 \\
\hline Cervantes Saavedra & 14 & 1 & 26 \\
\hline Mira Amescua & 47 & 1 & 46 \\
\hline
\end{tabular}




\begin{tabular}{|l|c|c|c|}
\hline Tirso de Molina & 17 & 0 & 36 \\
\hline Other Golden Age comedies & 21 & 0 & 28 \\
\hline E G Lobo & 26 & 0 & 10 \\
\hline Sonetos & 113 & 0 & 88 \\
\hline Total & 363 & 2 & 366 \\
\hline Percentage among diphthongs & 99.45 & 0.54 & \\
\hline
\end{tabular}

The much more common $u i$ combinations show even more overwhelming results: we found 363 rising-like diphthongs $(99.45 \%)$ for only 2 falling-like ones $(0.54 \%)$. With a much more extensive sample of cases, we see the percentage of falling-like diphthongs shrinking considerably. The two lone examples of falling-like examples are (8) and (9).

(7) Esta noche, y no durmiendo, porque entre el sueño y mis cuitas nunca el reposo hizo treguas, ni de veras ni de burlas, 'Last night, and while not sleeping, 'cause between sleep and my worries, rest never found a break not for real, not in jest,' (Digital Play Texts, Cervantes Saavedra: El laberinto de amor, verses 2325-2328)

(8) una ingratitud soberbia, un frenesí y un descuido. No niegues que soy tu esposo, que yo el derecho renuncio 'arrogant in gratitude, frenzy and carelessness. Don't deny I am your husband, since I renounce my rights.' (Digital Play Texts, Mira de Amescua: El palacio confuso, verses 3045-3048)

Both of these examples are instances of vowel rhyme. In (7), we find the word cuitas 'worries' rhyming with burlas 'jest' in a [u]-[a] pattern. Similarly, in (8) we find 
descuido 'carelessness' rhyming with renuncio '(I) renounce' in a $[\mathrm{u}]-[\mathrm{o}]$ pattern. It is clear therefore that in the two examples it is the first vocoid of the diphthong that acts as the syllabic nucleus, thus rendering a falling-like diphthong. There is no possibility of hiatus in either case, as only a diphthong will produce the required 8-syllable verse.

Examples of rising-like diphthongs are a lot more common. We list three here:

(9) que si casado no fui

con Otavia, culpa tuvo

su padre, que airado estuvo

sin ofensa contra mí.

'Since, if I wasn't married

To Otavia, it was because

of her father, who was angry

at me for no reason.'

(Artelope: El valor de las mujeres, verses 2760-2763)

(10) Cuando triunfo tan propicio

me conduce la ventura,

será especie de cordura

el saber perder el juicio.

Arda, humilde sacrificio,

'When such opportune success

Fortune brings me,

It must be a form of sanity

to know how to go out of my mind.

Let it burn, humble sacrifice,'

(Álvarez Amo, 2014, p. 226)

(11) Me quedaré sin puerta y sin ventana

habitando el silencio y el olvido,

ni habrá luz en mis ojos ni habrá ruido

que turbe mi vivir de porcelana.

'I will remain with no door or window,

living in silence and oblivion,

there'll be no light in my eyes, nor noise

to bother my porcelain life.'

(García González, 2007: Autores Letra B, p. 49)

In (9), the word fui 'I was' rhymes with the pronoun $m i$ ' $m e$ ' in full rhyme, according to the metric context. In (10), we find a three-way full rhyme for juicio 'judgement, 
mind' with propicio 'opportune' and sacrificio 'sacrifice'. Both examples require the presence of a diphthong in order to follow the 8-syllable verse pattern. Finally, in (11), ruido 'noise' rhymes with olvido 'oblivion', and again only the diphthong produces the required 11-syllable verse. In all three cases, the second vocoid acts as the syllabic nucleus, the pattern found in rising-like diphthongs.

It may be worth considering whether the examples with falling-like diphthongs follow the etymological pattern proposed by Real Academia Española (1973), where the diphthong would respect the original stress pattern of the word in Latin. This seems to be the case for the lone word found in an iu falling-like rhyme (viuda), where the vowel respects the etymological stress. Nonetheless, we find other examples of the same word in a rising-like rhyme (as in (4)), from a different author and timeframe. This may also mean that the word may be lexically specified as having one kind or diphthong or the other for different speakers.

As for $u i$ diphthongs, the issue is less clear, since not all authors seem to agree on the etymology of the words found in falling-like diphthongs in our sample (cuita, descuido; see for instance Corominas, 1973). In any case, even if we assume that the falling-like diphthong respects the original stress pattern, we find examples of the same words in rising-like diphthongs in authors from differing periods, leaving again open the option that the type of diphthong used for these words may be lexically specified differently for different speakers. A chronological change for these words from falling-like to rising-like may not be discarded either, but it would require further study.

\section{Conclusion and proposals for further study}

The study of the data from a representative sample of verses leaves little doubt as to the phonological status of homogeneous diphthongs in Spanish. Most of the reviewed literature on the topic proposes that these diphthongs behave like rising diphthongs. The data from the rhyming patterns agree with that proposal, showing that Spanish has a strong preference to classify homogeneous diphthongs as rising-like. Therefore, we must conclude that the preferred order of the vocoids in homogeneous diphthongs in Spanish is glide-vowel. The examples where rhyming patters showed the opposite order (vowelglide) are almost non-existent. We found little difference between the behavior of the two versions of homogeneous diphthongs: both $i u$ and $u i$ showed a strong preference for the rising like versions ([ju] and [wi] respectively). We did find that the first version $(i u)$ is far less frequent than the second $(u i)$ in our sample, and probably overall, both in the number of words that contained them and also in the frequency of those words.

We also found a strong tendency for these vocoid combinations to be pronounced as a hiatus, rather than a diphthong. Our survey found almost as many hiatuses as diphthongs in the studied sample. 
Of course, it may be desirable to expand the data in this study to get a greater sample of diphthongs. Our sample includes close to four hundred cases of homogeneous diphthongs, but as said above, there is a small minority of cases of the diphthong $i u$. It would be a good idea to extend the study to cover more examples of this specific diphthong in order to strengthen the conclusions of the study.

Also, given the suggestions in the literature about the idiolectal or dialectal variation in the shape of these diphthongs, it would also be interesting to further the study and classify the data according to author and geographical origin. However, since we know that more formal varieties of language tend to lose or reduce dialectal differences (see, for instance, Romaine, 2003), it would be difficult to ascertain exactly the dialect used by any author in highly formal language, such as the one used in poetry or theatre in verse. A more promising avenue for future research would be to find patterns where certain words may be lexically determined as having a specific kind of diphthong for individual authors.

It would also be interesting to study if there have been chronological changes regarding the status of homogeneous diphthongs. While it is plausible that there has been a change of status over time, the evidence collected in this study does not shed much light on this issue. A more detailed study with a better balance of data across the different centuries would be necessary to find if there has been a chronological change.

In any case, the data studied in this article support the definite preference in the Spanish language for pronouncing homogeneous diphthongs as rising-like diphthongs, at least with respect to the rhyming patterns that characterize the literary works analyzed in this study.

\section{References}

Alarcos Llorach, E. (1964). Fonología española. Madrid: Gredos. Artelope $=$ Universitat de València (2012).

Álvarez Amo, F. J. (2014). Las obras poéticas líricas (1738) de Eugenio Gerardo Lobo: edición y estudio. Córdoba: Servicio de Publicaciones de la Universidad de Córdoba.

Association for Hispanic Classical Theater. Digital Play Texts. Retrieved from http:// www.wordpress.comedias.org/play-texts/

Azevedo, M. (2009). Introducción a la lingüistica española (3rd ed.). Upper Saddle River, NJ: Prentice Hall.

Bello, A. (1884). Opúsculos gramaticales. Obras completas de Don Andrés Bello (Vol. V), Santiago de Chile: Pedro G. Ramírez.

Cloutier, C. (2007). Introducción al análisis lingüistico: sintaxis, fonología, dialectología y lingüistica histórica. Boston: McGraw-Hill.

Corominas, J. (1973). Breve diccionario etimológico de la lengua castellana (3rd ed.). Madrid: Gredos.

Cortez de Andersen, D. C. (2010). Contornos del habla: fonología y fonética del español. New Haven: Yale University Press. 
D’introno, F., Del Teso, E., \& Weston, R.(1995). Fonética y fonología actual del español. Madrid: Anaya.

Digital Play Texts $=$ Association for Hispanic Classical Theater (n.d.)

Eguren, L., \& Fernández Soriano, O. (2006). La terminología gramatical. Madrid: Gredos.

García González, R. (ed.) (2007). Biblioteca del soneto. Alicante: Biblioteca Virtual Miguel de Cervantes. Retrieved from http://www.cervantesvirtual.com/bib/portal/ bibliotecasoneto/

Gili Gaya, S. (1966). Elementos de fonética general. Madrid: Gredos.

Gómez Torrego, L. (2002). Gramática didáctica del español. Madrid: SM.

Harris, J. W. (1969). Spanish Phonology. Cambridge: MIT Press.

Harris, J. W. (1983). Syllable Structure and Stress in Spanish. Cambridge: MIT Press.

Hualde, J. I. (2005). The Sounds of Spanish. Cambridge: Cambridge U. Press.

Hualde, J. I., Olarrea, A., Escobar, A. M., \& Travis, C. E. (2010). Introducción a la lingüistica hispánica (2nd ed.). Cambridge: Cambridge U. Press.

International Online Archive of the Pan-Hispanic Ballad = University of Washington (n.d.)

Iribarren, M. C. (2005). Fonética y fonología españolas. Madrid: Síntesis.

Manrique, A. M. B. de (1979). "Acoustic Analysis of the Spanish Diphthongs", Phonetica, 36, 194-206.

Morgan, T. A. (2010). Sonidos en contexto. New Haven: Yale U. Press.

Navarro Tomás, T. (1957). Manual de pronunciación española (8th ed.). Madrid: CSIC.

Núńez Cedeńo, R. A., \& Morales-Front, A. (1999). Fonología generativa contemporánea de la lengua española. Washington: Georgetown U. Press.

Quilis, A. (1988). Fonética acústica de la lengua española. Madrid: Gredos.

Quilis, A. (2003). Principios de fonología y fonética españolas (5th ed.). Madrid: Arco/ Libros.

Quilis, A. \& Fernández, J. A. (1979). Curso de fonética y fonología españolas para estudiantes angloamericanos. Madrid: CSIC.

Real Academia Española (1973). Esbozo de una nueva gramática de la lengua española. Madrid: Espasa-Calpe.

Romaine, S. (2003). "Variation in Language and Gender". In J. Holmes \& M. Meyerhoff (Eds.), Handbook of language and gender (pp. 98-118). Oxford: Blackwell.

Universitat de València (2012). Artelope. Base de Datos y Argumentos del Teatro de Lope de Vega. Retrieved from http://artelope.uv.es/

University of Washington (n.d.). International Online Archive of the Pan-Hispanic Ballad. Retrieved from https://depts.washington.edu/hisprom/ballads/index.php 